\title{
Ethno-medicinal Uses of Animals and Plants among the Migratory Tangbetons of Pokhara, Nepal
}

\author{
Ranju Paudyal ${ }^{1}$ and N. B. Singh ${ }^{2}$ \\ Central Department of Zoology \\ Tribhuvan University, Kirtipur, Kathmandu \\ 'Email: paudyalranju@gmail.com \\ ${ }^{2}$ Email: nanda_nepal@yahoo.com
}

\begin{abstract}
This paper attempts to study various uses of medicinal animals and plants among the migratory Tangbetons of Nepal who were migrated to Pokhara Sub-Metro Politian City from Tangbe Village in Mustang district. Direct observation, questionnaire survey and key informant interview were conducted during the study period. Information about the medicinal plants and animals were given mainly by the Amchi and their information was taken from the elder persons. Finally, this paper recorded 17 medicinal animal species and 60 widely used medicinal plant species for the treatment of various diseases.
\end{abstract}

Key words: Indigenous knowledge, ethnic group, diseases, species.

\section{INTRODUCTION}

Nepal, having 1,47,181 sq.km area is naturally beautiful, varied with biodiversity having Sagaramatha as the highest peak in the world. Plants and animals and their products are the primary source of medicine and highly valued resource of Nepal, especially of the rural area which is dependent on the locally available medicinal animals and plants to cure the disease. These people have specific knowledge for using plants and animals. Ayurveda, Amchi, Naturopathy etc. are important traditional health care systems existing in Nepal. Complementary and Alternative Medicine (CAM) is being increasingly used by consumers to prevent disease and promote health in general. Perception of patients visiting the traditional medicine based centres and the hunger towards moreeffective service provision by the providers seems to be taking these systems of medicine towards the path of furtherdevelopment. Well recognition and further motivation by the state will help capacitate and strengthen these systemsof medicine and garner their proper development in the Nepalese context (Gewali, 2008; Koirala et al. 2013).

Nepal is a multi-ethnic, multi-lingual and multi-religious nation with about 126 ethnic groups speaking about 123 dialects (Bista, 1987; Bista, 2004; CBS, 2012). The knowledge system may be different in same ethnic group due to geographical variation. The contribution of biodiversity to the health of the people in the region is extremely important because 80 percent of the people rely on traditional herbal medicine for their health care. Biodiversity and bio-resoureces have high affinity in the case of ethnic groups in Nepal (Singh, 1995; Singh, 1997). Lama et.al (2001) has published a book on 100 medicinal plants of Dolpa that gave emphasis on Amchis' knowledge and conservation. Tangbetons are the ethnic group having small number of population. Populations of Tangbetons have not been described in any Census of Nepal. So it was difficult to get the exact number of population of Tangbetons in Nepal. There are about 32 households in Tangbe Village, about 100 families in Pokhara, around 25 families in Jomsom, around 20 families in Kathmandu. The estimated studied population of Tangbetons in Pokhara seems to be around 500 by using the average family size of 4.88 per family of Nepal in 2011 (CBS, 2012). However, the total estimated population may be around 1000 in Nepal. Majority of them are mainly found in Pokhara. Indeed, these are the original inhabitants of Tangbe Village that lies in Mustang District. These groups are influenced by the Tibetan Medicine System. So the healers of these groups are known as Amchi, who prepare medicine by the use of available plants and animals. In this context, this paper attempts to explore and then document the various uses of medicinal animals and medicinal plants for the treatment of different diseases found among Tangbetons.

\section{MATERIALS AND METHODS}

Pokhara Sub-Metro Politan City is situated in the Kaski district, western development region of Nepal. Prithvi 
chowk, Srijana chowk, New road, Mahendrapool and Chipledunga in Pokhara are some of the study areas in which about 100 families of migratory Tangbetons are distributed.

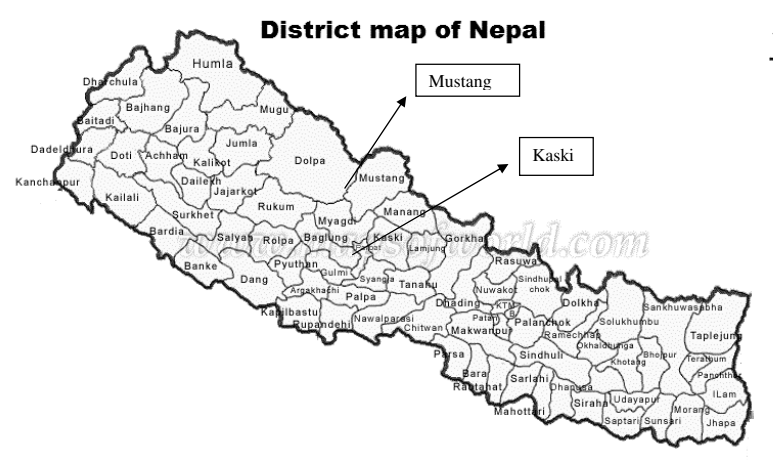

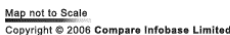

Shorea robusta (Sal), Bideus pilosa (Kuro), Artemisia vulgaris are the important flora and Corvus splendens (Crow), Panthera pardus (Common Leopard) are important fauna found in Pokhara. Tangbetons are inhabitants of Mustang district, the important flora found here are Rhododendron arboreum, Arnebia benthamii, fauna found here are Capra hircus (Wild goat), Bos grunniens (Yak) Canis aureus (Jackal) etc.

This study was conducted from Sept 2010 to April 2011. The interview was mainly taken with a group of Amchis in order to get the knowledge of medicinal animals and plants being used in Tangbetons for decades. Other elderly people were also interviewed with a view to explore and document the indigenous knowledge system found in the Tangbetons. The plants and animals used by the Amchi for the medicinal value were identified mainly by themselves. In our research work, we included two different ways of data collection. Under primary data collection we included the questionnaire survey, key informants interview and field works. Between above mention time period, we visited the study area many times. We directly observed some of the animals and plants used by Tangbetons, and we also took the photos of those observed animals and plants. These pictures were also used to identify the animals and plants that they are used for medicinal uses. Primary information were compared to that of the available secondary information in order to make the results more reliable and valid. The secondary information were taken from published and unpublished sources such as books, journals, research notes and reports, academic papers, dissertations and theses, etc.

\section{RESULTS}

Animal, plant, nature and human beings have intimate association with one another along with the advancement of human civilization which finally led the indigenous people like Tangbetons to know the use of natural resources in a more needy way. Tangbetons had some different type of indigenous knowledge and they even had the knowledge about different medicinal plants and animals and the utilization of those species. Those people do not have their own group traditional healer, so they depend upon the Tibetan Amchi to cure different diseases. The study showed that they make use of the 60 species of medicinal plants belonging to 40 families and 17 species of animals belonging to 8 orders and 12 families for medicinal purpose. Animal species were used to cure arthritis, thyroidism, diarrhea, over bleeding, etc. Plant species were used for purification of blood, backache, joint pain, B.P, diabetes, common cold etc. This study was based on the migratory Tangbetons found in the some areas of Pokhara, so the people living there use both Traditional and Modern health facilities. The elderly people who come to visit their relatives in Pokhara from Mustang use the medicine from Amchi. Following table shows some medicinal practices among the Tangbeton people.

Table 1. Categorization of animal species used in folk medicine by the migratory Tangbetons of Pokhara Valley

\begin{tabular}{|l|l|l|l|l|}
\hline S.N. & \multicolumn{1}{|c|}{ Animals } & $\begin{array}{c}\text { Nepali/Local } \\
\text { Name }\end{array}$ & \multicolumn{1}{|c|}{ Organ Used } & \multicolumn{1}{|c|}{ Medicinal Uses } \\
\hline 1 & Bos grunniens (Yak) & Chauri/Hya & Horn, Meat, Blood & $\begin{array}{l}\text { Heat Body, Digestion, Provides Energy, } \\
\text { Heat the BodyDiarrhoea, Fever }\end{array}$ \\
\hline 2 & Capra hircus (Chyangra) & Chyangra/Ramo & Meat & Strength \\
\hline 3 & Capra hircus (Goat) & Bakhra/Khasi & Meat & Pain on the Limbs, Heats the body \\
\hline 4 & Bos indicus (Cow) & Gai/Memo & Urine & $\begin{array}{l}\text { Joint pain, Swelling, Water Deposition } \\
\text { inside the joints }\end{array}$ \\
\hline 5 & Ovis ammon hodgsoni (Sheep) & Bhenda/Ghyu & Meat & Rheumatism \\
\hline 6 & Moschus Chrisogaster (Deer) & Mirga/Fo & Meat, Fat & $\begin{array}{l}\text { Over Bleeding, Menstural Imbalance, } \\
\text { Sinusitis }\end{array}$ \\
\hline 7 & Canis aureus ( Jackal) & Syal/Syala & Meat & Rheumatism, Arthritis \\
\hline 8 & Panthera tigris ( Tiger) & Bagh/Taa & Bone & Body Pain, Energy \\
\hline
\end{tabular}




\begin{tabular}{|l|l|l|l|l|}
\hline 9 & Columba livia (Pigeon) & Parewa/Dokhen & Stool & Abscess \\
\hline 10 & Gyps himalayaensis (Vulture) & Giddha/jyake & Meat & Thyroidism, Heats the Body \\
\hline 11 & Apis cerana (Bee) & Mauri & Honey & Cough, Common Cold \\
\hline 12 & Periplaneta Americana (Cockroach) & Sangle kira & Whole Body & Severe pain as like Appendicitis \\
\hline 13 & Equus hemoionus kiang (Horse) & Ghoda/Ta & Nail & Stiffening of the stomach \\
\hline 14 & Equus kiang (Donkey) & Gadha/Bumbu & Blood, Meat, Nail & $\begin{array}{l}\text { Joint pain, Diarrhoea, Water Deposition in } \\
\text { the Body }\end{array}$ \\
\hline 15 & Rhinoceros unicornis (Rhino) & Gainda & Skin & Makhya \\
\hline 16 & Homo sapiens (Human) & Manche/Mhi & Urine & Eye Pain, Conjuctivitis \\
\hline 17 & Apodemus gurkha (Mouse) & Musa/Nami & Skin & Abscess \\
\hline
\end{tabular}

Table 2. Categorizatios of plant species used in folk medicine by the migratory Tangbetons of Pokhara Valley

\begin{tabular}{|c|c|c|c|c|}
\hline S.N & Plants & $\begin{array}{c}\text { Nepali/Local } \\
\text { Name }\end{array}$ & Parts Used & Medicinal, Uses \\
\hline 1 & Justicia adhatoda & \begin{tabular}{|l|l} 
Asuro \\
\end{tabular} & Seed & Purification of Blood \\
\hline 2 & Allium sativum & Lasun/Nho & Bulb & Gastritis, Disorder Sleep, Cancer Disease \\
\hline 3 & Acorus calamus & Bojho & Root & Throat Pain, Common Cold \\
\hline 4 & Saussurea graminifolia & & Whole Part & Kidney Fever, Bile Disorder, Sores \\
\hline 5 & Arnebia benthamii & $\begin{array}{l}\text { Unknown/ } \\
\text { Dimok }\end{array}$ & Root, Bark & Chronic fever, Swelling, Poisoning \\
\hline 6 & Cannabis sativa & Bhang & Seed & Purify Blood \\
\hline 7 & Terminalia bellirica & Barro & Fruit & Throat pain, Cough \\
\hline 8 & Terminalia chebula & Harro & Fruit & Gastritis, Purification of Blood \\
\hline 9 & Brassica compestris & Tori/Nanam & Seed,Leaves & Back ache, Joint Pain, Massage Cream,Thorn \\
\hline 10 & Brassica juncea & Rayo/Daf & Leaves & Digestion, Good for Eye \\
\hline 11 & Brassica rapa & Salgam/Muli & Root & Digestion \\
\hline 12 & Lepidium sativum & Chamsur & Whole Plant & Body Pain, Heat the body \\
\hline 13 & Raphanus sativus & Mula/Lhau & Leaves, Root & Gastritis, Digestion \\
\hline 14 & Leucartha & Lauka & Fruit & High Blood Pressure \\
\hline 15 & Memordica charantia & Karela & Fruit & High Blood Pressure \\
\hline 16 & Juniperus squamata & Shuk & Seed,Leaves & Nasal Bleeding, Digestion, Blood disorder \\
\hline 17 & Elaeocarpus nerefolia & Rudraskhya & Seed & Water Deposition inside the joints \\
\hline 18 & Ephedra gerardiana & & Seed, Leaves & $\begin{array}{l}\text { Kidney Fever, Cough, Heart Disease, Blood } \\
\text { Pressure, Excessive Bleeding }\end{array}$ \\
\hline 19 & Rhododendron arboretum & $\begin{array}{l}\text { Gurans/ } \\
\text { pathamhendo }\end{array}$ & Flowr & Remove stuck thorn of Fish \\
\hline 20 & Emblica officinalis & Amala & Fruit & Gastritis, Purification of blood, Good for eye \\
\hline 21 & Swertia chirayita & Ciraito & Whole plant or Leaves & Fever, Pneumonia, Jaundice \\
\hline 22 & Hordeum vulgare & Uva/Karu & Seed & Stone on Gall Bladder \\
\hline 23 & Oryza sativa & Dhan/Mrhasin & Seed, Grain & Diabetes, Diarrhoea \\
\hline 24 & Saccharum officinarum & Ukhu & Stem & Diarrhoea \\
\hline 25 & Cordyceps sinensis & Yarsagumba & Whole Plant & Jaundice \\
\hline 26 & Ocimum sanctum & Tulasipatra & Leaves & Good to Kidney, Vitamin, Strength to the body. \\
\hline 27 & Dracocephalum tanguticum & $\begin{array}{l}\text { Not known/Ti } \\
\text { yang ku }\end{array}$ & Root & Common Cold,Cough \\
\hline 28 & Cinnamomum tamala & Tejpat & Leaves & $\begin{array}{l}\text { Digestive Disorder, Wind disorder, Kidney } \\
\text { Disease }\end{array}$ \\
\hline 29 & Dodecadonia grandiflora & Nepali Dalchini & Stem & Good for Kidney \\
\hline 30 & Oxytropis sp. & Tak Sha & Leaves,Flower,Fruits & Gastritis \\
\hline 31 & Trigonella foenum & Methi & Seed,Grain & $\begin{array}{l}\text { Dysentry, Vomiting, Fever, Cut, Poison, Wound, } \\
\text { Sore, }\end{array}$ \\
\hline 32 & Allium wallichii & Jimbu & All part & Sinusistis \\
\hline 33 & Aloe barbadensis & Gheukumari & All part except Root & $\begin{array}{l}\text { Common Cold, Gasrict, Digestion, Good for eye, } \\
\text { Cough }\end{array}$ \\
\hline 34 & Asparagus racemosus & Kurilo & Stem & $\begin{array}{l}\text { Burnt Area, High Blood Presssure, Spots on the } \\
\text { skin }\end{array}$ \\
\hline 35 & Azadirachta indica & $\mathrm{Nim}$ & Leaves & Energetic \\
\hline 36 & Ficus bengalensis & Bar & Seed & Fever, Cough \\
\hline 37 & Betula utillis & Bhote Pipal & Bark & Dandruff \\
\hline
\end{tabular}




\begin{tabular}{|l|l|l|l|l|}
\hline 38 & Myristica fragrans & Jaiphal & Seed & Leg Fracture \\
\hline 39 & Dactylorhiza hatagirea & Panca angule & Root & Piles \\
\hline 40 & Areca catechu & Supari & Fruit & Strength, Vitamin \\
\hline 41 & Dolichus biflorus & Gahat & Seed & Good for Kidney \\
\hline 42 & Parnassia nubicola & Nirmashi & Seed,Grain & Kidney Stone \\
\hline 43 & Seasumum orientale & Til & Seed,Grain & Fever \\
\hline 44 & Plantago depressa & & Whole Part & Gastritis, Teeth and Eye Problem \\
\hline 45 & Pisum sativum & Kerau & Flower & Vomiting, Good for Lymph Fluid \\
\hline 46 & Fagophyrum esculentum & Phapar & Seed, Grain & Cure Stomach Pain during Mensturation \\
\hline 47 & Punica granatum & Anar & Fruit & Jaundice \\
\hline 48 & Prunus persica & Aru & Seed & Gastrict, Balances Haemoglobin, Pressure \\
\hline 50 & Citrus aurantifolia & Kagati & flowers, Fruit, Bark & Ear Pain \\
\hline 51 & Zanthoxylum armatum & Timur & Fruit & Diarrhoea, Liver disease, Swelling of Stomach \\
\hline 52 & Picrorhiza crophulariflora & Kutki & Whole Plant, Root & Common Cold, Cough \\
\hline 53 & Solanum surattense & Kantakari & Fruit & $\begin{array}{l}\text { Fever, Cough, Diarrhoea, Typhoid, Headache, } \\
\text { Purification of Blood }\end{array}$ \\
\hline 54 & Carum carvi & Jira/Jiri & Seed & Mental Disorder, Fever, Eyes Problem \\
\hline 55 & Coriandrum sativum & Dhaniya & Seed & Common Cold Cough \\
\hline 56 & Vitis vinifera & Angur & Fruit & Vomiting \\
\hline 57 & Ammomum subulataum & Alainchi & Seed & Cough, Good for Lungs \\
\hline 58 & Curcuma longa & Besar & Rhizome & Indigestion, Vomiting \\
\hline 59 & Elettaria cardamomum & Sukmel & Fruit & Cut, Wound Parts, Common Cold, Cough \\
\hline 60 & Zingiber officinale & Aduwa & Rhizome & $\begin{array}{l}\text { Kidney Problem, Throat Pain, Cough, Gastritis, } \\
\text { Diabetes }\end{array}$ \\
\hline
\end{tabular}

\section{DISCUSSION AND CONCLUSIONS}

Although Tangbetons are one of the indigenous ethnic groups of Nepal originally from the Bahra Gaunle, Chhusang village in Mustang district, but their population is not recorded yet in the National Population and Housing Census in Nepal 2011 (CBS, 2012). Those people utilized the natural resources in their area many years before and even today they are practicing their indigenous system in Jomsom, Pokhara, and Kathmandu where they have been migrated. Tangbetons have indigenous knowledge to utilize the plant and animal species for medicinal purposes at local level. This study revealed the utilization of 17 species of medicinal animals and different 60 species of medicinal plants both wild and domesticated by Tangbetons to cure various diseases. The different parts of animals used were horn, bone, meat, blood, gall bladder, fat, brain, skin, nail, urine, stool, hair and whole body for the treatment of different diseases as diarrhea, fever, joint pain, rheumatism, thyroidism, eye pain, swelling etc. Whereas the different parts of plants used were stem, root, fruit, bark or whole part of the plants were used to cure Jaundice, diarrhea, dysentery, typhoid, piles, blood pressure, mental disorder, diabetes, kidney fever, sinusitis etc. The way they used medicine was orally as internal medication and external medication.

The different species of plants and animals reported with their traditional medical therapy in the present research work are also supported by the findings of other researches for different purposes, like Aloe barbadensis is used for the burn, high blood pressure and spots on the skin in the present study. Ghimire (1999), Tamang (2003), and Dhami (2010) reported the same species for digestive disorder, curing cough and the treatment of boil. Present study documented the use of Terminalia chebula is for gastritis and purification of blood whereas Pangeni (2005) and Dhami (2010) reported the same species for chronic ulcer wound and the treatment of rheumatism. The present study also explored the use of Cannabis sativas for the purification of blood whereas Dhami (2010) clearly reported that Cannabis sativa was also used for the treatment of rheumatism, arthritis and pain.

Similarly Zingiber officinalae, Zanthoxylum armatum, Prunus persicca, Dolichus biflorus, Ocimum sativum, Acorus calamus were also supported by the findings of other researchers for similar use (GON 1984 \& 1994; Ghimire \& Thomas, 2002; Pandey, 2006; Joshi \& Joshi 2007). Finally, the utilization of different 60 species of medicinal plants and 17 species of medicinal animals both wild and domesticated was found in Tangbetons to cure various diseases.

Tangbetons depend on Lama for their cultural rites whereas on Amchi for their treatment to various disease. The migratory Tangbetons do not have their own Amchi they depend on the Tibetan Amchi as they are greatly influenced by the Tibetan culture. Most of 
them are Buddhist, and avoid sacrificing the animals but Tangbetons feasts and festivals are incomplete without meat.

There are different types of Indigenous Knowledge System found in the Tangbetons. To name few are storage of seeds and food grains, preparation of indigenous drink 'Pa gheun' and 'Pa jhi', preparation and use of materials from locally available resources. These sorts of indigenous knowledge system are transmitted to the young generation of Amchis by verbal communication as well as some documentation in Tibetan language. The Amchi system of treatment of various diseases by the use of medicinal animals and plants is a unique system in the trans-Himalayan range across Northern border of Nepal.

\section{ACKNOWLEDGEMENT}

We are highly indebted to Central Department of Zoology, T.U, and Kirtipur for all sorts of cooperation extended during our study period. We are also grateful to the people of the study area who shared their knowledge on medicinal plants and animals, they were Amchi Tenzin Bista, Mahendra Gurung (Tangbe), and Sanyam Tangbe.

\section{REFERENCES}

Bista, D.B. 1987. People of Nepal. $5^{\text {th }}$ Edition. Ratna Pustak Bhandar, Kathmandu, Nepal.

Bista, D.B. 2004. People of Nepal. Ratna Pustak Bhanda, Kathmandu, Nepal

CBS (2012). National Population and Housing Census 2011, Volume 01, November, National Planning CommissionSecretariat, Kathmandu, Nepal.

Dhami, G.S. 2010. Ethnobiology of Pahari: A case study of Badikhel VDC of Lalitpur District. M.Sc. Thesis, Central Department of Zoology, T.U, Kirtipur Kathmandu, Nepal.

Gewali, M. B. 2008. Aspects of Traditional Medicine in Nepal, Institute of Natural Medicine, University of Toyama, Japan.

Ghimire, K. 1999. Ethno-medico-botany of Tharu tribe of Nawalparasi District. Study report submitted to DNPWC. Ghimire, S.K. and Thomas, Y.A. 2002. Approaches to Insitu Conservation of Threatened Himalayan Medicinal Plants: A Case Study from Shey Phoksundo National Park, Dolpo. Himalayan Medicinal and Aromatic Plants, Balancing Use and Conservation. Proceedings of the Regional Workshop on wise Practices and Experiential Learning in Conservation and Management of Himalayan Medicinal Plants, Kathmandu, Nepal.
Government of Nepal (GON) 1984. Medicinal Plants of Nepal (supplement Volume). Bulletin of Department Medicinal Plants No.10 His Majesty's Government of Nepal, Ministry of Forest and Soil Conservation, Kathmandu.

Government of Nepal (GON) 1994. Medicinal Plants of Nepal. Bulletin of Department Medicinal Plants No.3, His Majesty's Government of Nepal, Ministry of Forest and Soil Conservation, Kathmandu.

Joshi, A.R. and Joshi, K. 2007. Indigenous Knowledge and Uses of Medicinal Plants by Local Communities of the Kaligandaki Watershed Area, Nepal. Journal of Ethnopharmacology.73:175-183.

Koirala, R.R; Khaniya, B.N.; Singh, S.P.; Aryal, K.K. and Bhusal, C.L. 2013. Quality and Effectiveness of Service Provision

of Traditional Medicine Based Health Service Centres in Kathmandu, Nepal. J Nepal Health Res Counc. 11(24): 177-8.

Lama, Y.C.; Ghimere, S.K. and Thomas, Y.A. 2001. Medicinal Plants of Dolpo: Amchis' Knowledge and Conservation.

Published by WWF Nepal Program, Kathmandu, Nepal.

Pandey, M.R. 2006. Use of Medicinal Plants in Traditional Tibetan Therapy System in Upper Mustang, Nepal. Our Nature 4:69-82.

Pangeni, N. P. 2005. Ethnobiology of the Gurungs: A case study of Waling Muincipalityof Syangja district. A dissertation submitted to the $\quad \mathrm{C}$ e $\mathrm{n} \mathrm{t} \mathrm{r}$ a 1 Department of Zoology, Kirtipur, Kathmandu, Nepal.

Singh, N.B. 1995. Study on Ethnobiology of Endangered Tribe, the Raute. A dissertation Submitted to the Central Department of Zoology, Kirtipur, Kathmandu, Nepal.

Singh, N.B. 1997. The Endangered Raute Tribe: Ethnobiology and Biodiversity. GLORECA "ETHNOBIOLOGY" Kathmandu, Nepal.

Tamang, P. 2009. Medical Ethnobiology and Indigenous Knowledge System of the Lapcha in Nepal. A case study of Fikkal VDC, Illam District. M.Sc. Thesis, Central Department of Zoology, T.U, Kirtipur Kathmandu, Nepal. 